\title{
ArcheoSciences
}

Revue d'archéométrie

\section{Applied geophysics in archaeological prospecting at sites of Authumes (Saône-et-Loire) and Mirebeau (Côte-d'Or) (Bourgogne, Eastern France)}

Philippe Barral, Gilles Bossuet, Martine Joly, Michel Dabas, Christian Camerlynck, Laurent Aubry, Alain Daubigney, Matthieu Thivet and Stéphane Alix

\section{(2) OpenEdition}

1 Journals

Electronic version

URL: https://journals.openedition.org/archeosciences/1204

DOI: 10.4000/archeosciences.1204

ISBN: 978-2-7535-1599-4

ISSN: 2104-3728

Publisher

Presses universitaires de Rennes

\section{Printed version}

Date of publication: 30 October 2009

Number of pages: $21-25$

ISBN: 978-2-7535-0943-6

ISSN: 1960-1360

\section{Electronic reference}

Philippe Barral, Gilles Bossuet, Martine Joly, Michel Dabas, Christian Camerlynck, Laurent Aubry, Alain Daubigney, Matthieu Thivet and Stéphane Alix, "Applied geophysics in archaeological prospecting at sites of Authumes (Saône-et-Loire) and Mirebeau (Côte-d'Or) (Bourgogne, Eastern France)", ArcheoSciences [Online], 33 (suppl.) | 2009, Online since 30 October 2011, connection on 01 February 2022. URL: http://journals.openedition.org/archeosciences/1204 ; DOI: https://doi.org/10.4000/ archeosciences.1204 


\title{
Applied geophysics in archaeological prospecting at sites of Authumes (Saône-et-Loire) and Mirebeau (Côte-d'Or) (Bourgogne, Eastern France)
}

\author{
Philippe Barral*, Gilles Bossuet* and Martine Joly** \\ in collaboration with Michel DaBAs ${ }^{* * * *}$, Christian CAMERLYNCK ${ }^{* * *}$, \\ Laurent Aubri****, Alain Daubigney*, Matthieu Thivet*, Stéphane Alix****
}

Key words: Integrated geophysical survey, Rural LaTène settlement, Gallo Roman sanctuary, Resistivity map, Magnetic mapping.

\section{Authumes « Le Tertre » (SAÔNE-ET-LoIRE, BOURGOGNE)}

The most visible part of the archaeological site of Authumes (Burgundy, Eastern France) is the top of an escarpment which forms the limit separating the Bressan plateau from the floodplain of the Doubs River.

The importance and interest of the site are directly connected to the presence of archaeological material abounding on the ground. Numerous varied artefacts such as ceramic, architectural tiles, cut stones, can be found in a band (approximately $500 \mathrm{~m}$ long and $250 \mathrm{~m}$ wide) following the axis of the bank. In the higher part of the site, remains are particularly subject to erosion caused by ploughing. The available air photos supplied no indication on the heart of the deposit and only some small anomalies on its border. Without precise information about the nature and organiza- tion of the site, our first choice was a combination of various types of methods -photo-interpretation, field walking, excavations, and geophysical prospecting.

Magnetic mapping on an area of $9 \mathrm{ha}^{1}$, allowed detection of a network of narrow linear structures (ditches, drains, walls?) and strongly local magnetic anomalies, as well as a large-sized quadrangular structure (approximately $135 \mathrm{~m}$ by $115 \mathrm{~m}$ ), enclosed by a presumed wide filled ditch (Fig. 1).

The morphology and size of this quadrilateral enclosure suggest the existence of the ditch enclosing a rural La Tène settlement. The group of linear anomalies in the south part of the site possibly corresponds to numerous features of antique constructions overlapping the large La Tène enclosure.

Two soundings of approximately $50 \mathrm{~m}$ long and $5 \mathrm{~m}$ wide were carried out, one in 2000, the other in 2001 (Fig. 2). They showed first that the present topography could be related to

* UMR 6249, CNRS. Laboratoire de Chrono-environnement, Université de Franche-Comté.

** Université Paris-Sorbonne, Paris IV

*** UMR 6249, CNRS, Sisyphe 7619, Université Pierre et Marie Curie, Paris VI.

**** Société Terra Nova.

1. The magnetic survey has been carried out using the magnetometer G-858 MagMapper TM from Geometrics. The measurements in gradiometric mode were collected on square grids $(50 \mathrm{~m})$ in bidirectional pattern, by walking both up and down lines of $1 \mathrm{~m}$ spacing. The survey was made in continuous mode with readings taken at intervals of $0.1 \mathrm{~s}$ cycle time and sensitivity of $0.01 \mathrm{nT}$. Specific geophysical software Wumap was used for the processing of magnetic data (removal of "heading error" line effects, correction of herringbone effects and re-interpolation of processed data on a $50 \mathrm{~cm}$ square mesh). 

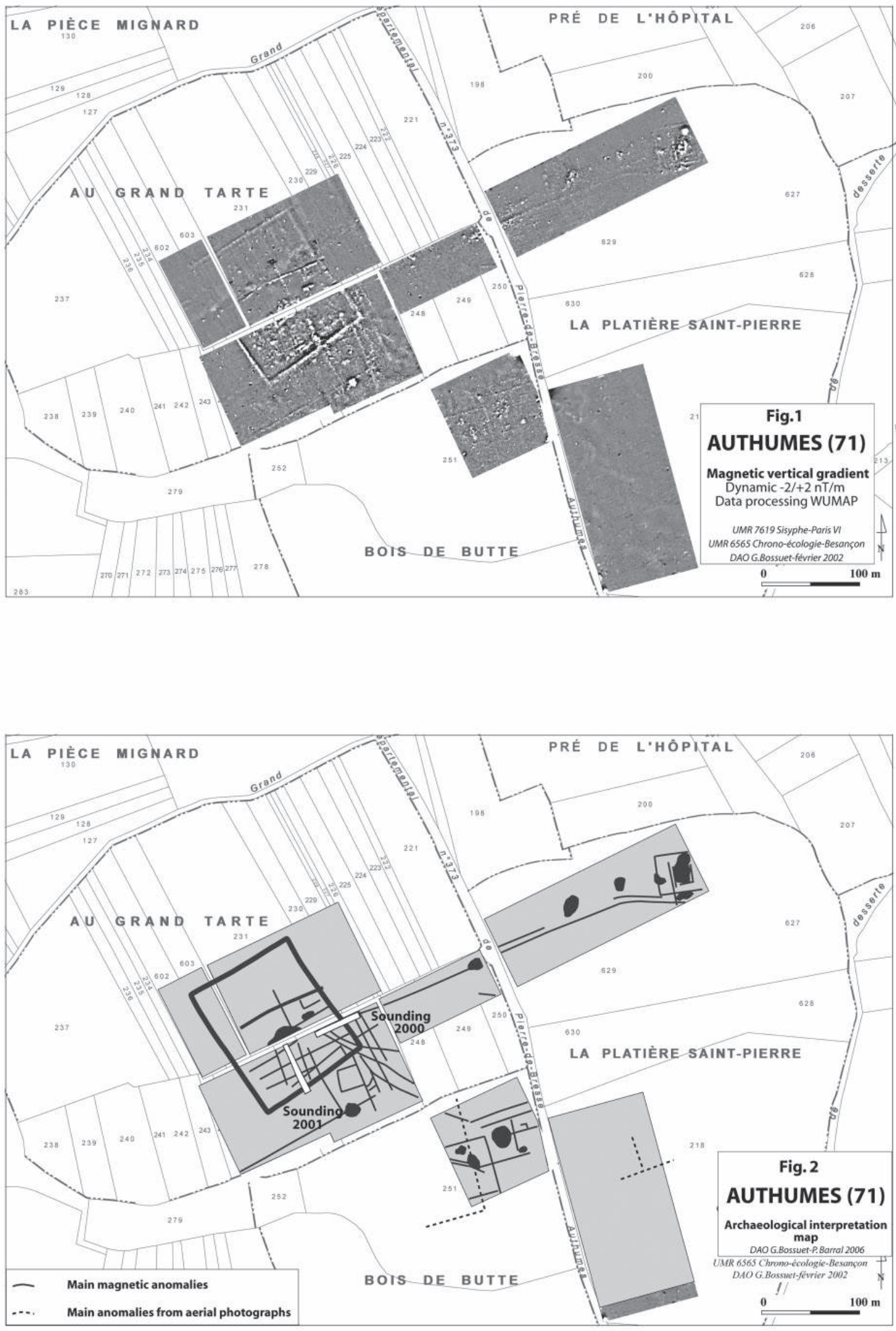

ArCheoSCIEnCes, revue d'archéométrie, suppl. 33, 2009, p. 21-25 
the Roman time. Indeed, the relief of the escarpment was profoundly remodelled during this period by the addition of fillings (layers of grave alternating with layers of clay). At that time, the aim of these diggings may have been to build a platform used as a basis for one or several antique constructions.

The excavated layers and structures belong to different chronological sequences (Fig. 3). A first sequence corresponds to an occupation of LaTène D (150-30 BC), in which a soil level of La Tène D2 (80-30 BC) is clearly identifiable. The second sequence corresponds to the GalloRoman occupation, until $1^{\text {st }}$ century AD.

Some of the Gallo-Roman structures can be related to anomalies in the magnetic mapping. The high magnetic response in pit and drain fillings can be explained by the concentration of tiles in demolition material.

The Gallic habitat is bounded by a wide (V shaped) quadrangular ditch which corresponds to a large-sized magnetic anomaly. The variations in the magnetic detection of the enclosure depend on topographic and geological factors. Amplitude of vertical gradient measurement is the highest at the top the escarpment and decreases as it goes down to the bottom of the floodplain.
Within the enclosure, an intricate network of hollow structures appears, among them, pits of extraction, drains, narrow ditches, holes of posts. The largest ones are better detected as they contain fragments of high magnetic susceptibility like carbonized cob walls.

This integrated approach allowed us not only to understand the history of the site in its main lines, but also its development and functions. This study equally permitted to identify the nature of Gallic occupation, understand its organisation and characterise its socio-economic status.

\section{Mirebeau-Sur-Bèze « La Fenotte » (CôTE-D'Or, Bourgogne)}

Lying some thirty kilometres north east of Dijon, the site "La Fenotte " in Mirebeau-sur-Bèze spreads at the very end of a low-altitude plateau, overlooking the valley of the Bèze River, one of the Saone's tributaries. The natural ground is mainly composed of slightly clayey yellowish silt. The site was discovered by aerial survey in 1973. The photographs clearly show buildings (two of them being temples of the
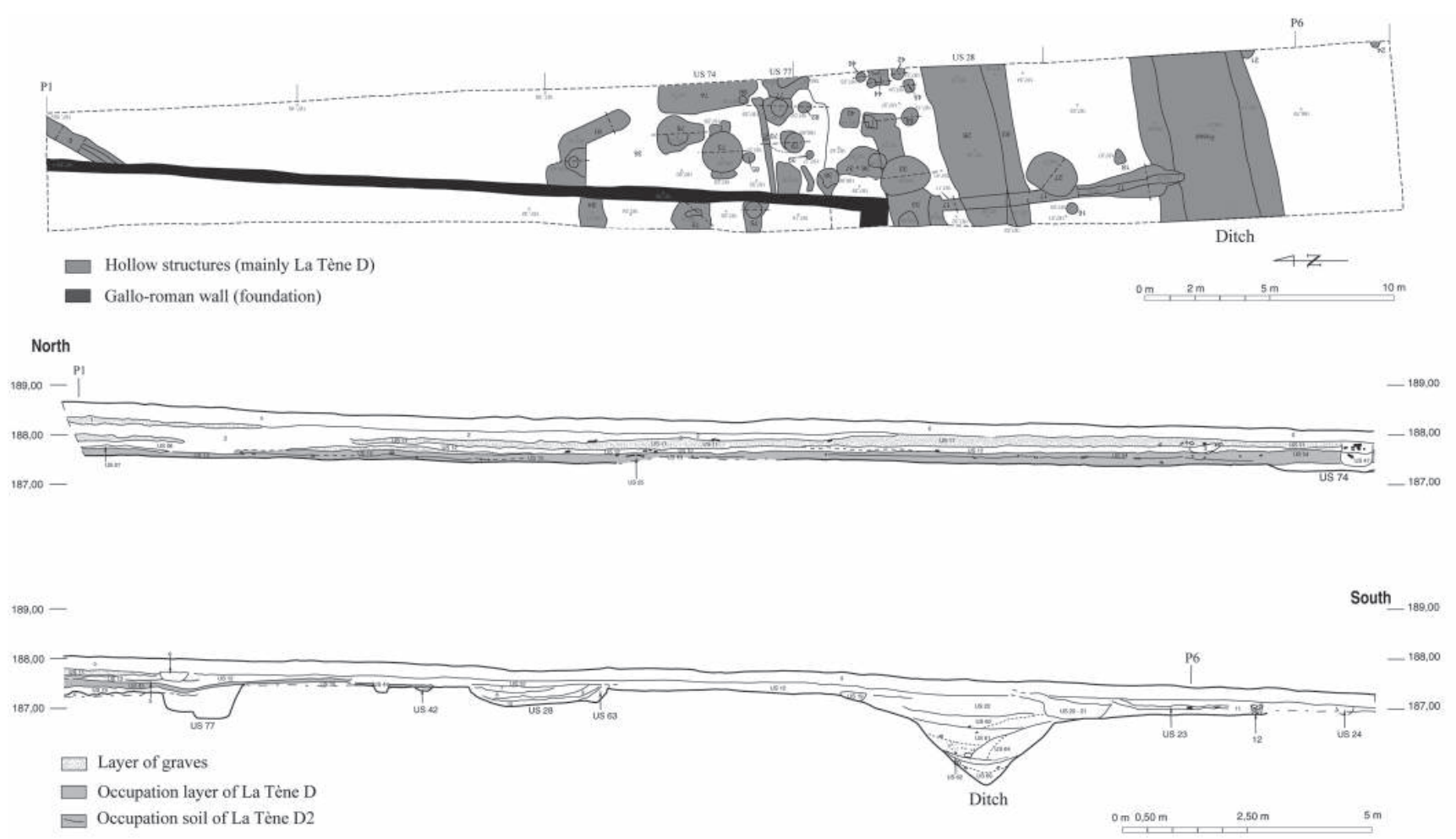

Fig. 3 - AUTHUMES (71)

Sounding 2001. Excavation plan of structures and longitudinal cross-section from East Releve et DAO : Ph. Barral, M. Thivet, 2001 
fanum type), as well as several linear structures and various localized anomalies (Fig. 1).

The excavations undertaken between 1978 and 1986 on the eastern part of the site allowed us to uncover several elements of what may have been a sanctuary: built structures of the Gallo-Roman period (the two temples F1 and F2, a double-walled gallery $\mathrm{B}$, underground pipework $\mathrm{C}$ ), as well as segments of a ditch, fence trenches, pits and post-holes from the Late Iron Age (south and west of the two temples).

Some of the sanctuary's components were discovered thanks to aerial photography and excavations, but the complex organization ruling over the places of worship remained unclear, particularly in the western part of the dig.

Prior to the in-depth excavation launched in 2001, a geophysical survey (electric and magnetic methods) was undertaken on the entire zone of worship. Only the resistivity survey was conclusive for this part of the site (Fig. 2) ${ }^{2}$.

Several persistent anomalies, already detected on aerial photographs, appear very clearly on the resistivity map (Fig. 3). It shows two temples of the fanum type (F1 and F2), a pipework called "aqueduct" (C) and two parallel walls called "gallery" (B). Aerial photographs also showed indistinct semicircular forms. The resistivity map shows several curvilinear anomalies laid out in concentric patterns. These anomalies, alternatively resistant and conductive, were laid out around a central zone, particularly marked by its resistivity (A). This part could be interpreted as enclosures, delimited with a system of ditches and embankments, surrounding a zone whose surface was once hardened by possible laying-out or simply human movement.

The structures' map, recorded on the dig (Fig. 4) corroborates and specifies most of the anomalies detected with the geophysical survey. The B gallery actually is a polygonal peribolus whose western and southern outlines, a ghost only a few centimetres deep, could hardly be found. Anomalies, E, G, I, H do correspond to buildings, here again ill-preserved (I is a cellar). Anomalies J, K and L could not be correlated with any structure found in the excavation. The phenomenon could be a side-effect of a thick earth-bank composed of destruction material.

Last, the structure in zone A was identified as an enclosure marked by a $3 \mathrm{~m}$ wide and 0,75 to $1 \mathrm{~m}$ deep ditch delimiting a zone characterised by a very thin sediment layer. This

2. It was performed with a resistance meter (RM15) coupled with a multiplexer (MPX15) by Geoscan Research. Electrodes were connected up in a "pole to pole" system. Two surveys, in different size grids, one thin $(1 \mathrm{~m} \mathrm{x}$ $1 \mathrm{~m})$, one larger $(2 \mathrm{~m} \times 2 \mathrm{~m})$ were simultaneously led. In fine, the resistivity map based on the $2 \mathrm{~m} \times 2 \mathrm{~m}$ grid becomes superfluous, compared with the $1 \mathrm{~m}$ grid survey here presented. central zone was associated with an ancient knoll, invisible in today's topography.

\section{References}

Barral, P., Bossuet, G., Daubigney, A., Camerlynck, C., Dabas, M., Lecomte, B. and Thivet, M., 2009. Un exemple d'approche intégrée d'un établissement de la fin de l'âge du Fer: Authumes "Le Tertre" (Saône-et-Loire), Actes de la Table ronde des 18-19 Novembre 2004. EHESS Toulouse (Centre d'Anthropologie - UMR 8555). L'exploitation agricole dans son environnement à la fin de l'âge du Fer. Nouvelles approches méthodologiques, under press.

Joly M. and BARraL P., 2008. Du sanctuaire celtique au sanctuaire gallo-romain: quelques exemples du nord-est de la Gaule. In Castella, D., Meylan Krause, M.-F. (dir.), Topographie sacrée et rituels. Le cas d'Aventicum, capitale des Helvètes, actes du colloque international d'Avenches, 2-4 novembre 2006, Archéologie Suisse, Antiqua 43, 2008, 217-228.

Joly M. and Barral P., 2007. Le sanctuaire de Mirebeau-surBèze (Côte-d'Or): bilan des recherches récentes, in Barral, P., Daubigney, A., Dunning, C., Kaenel, G., Rouliere-Lambert, M.-J., (dir.), L'âge du Fer dans l'arc jurassien et ses marges. Dépôts, lieux sacrés et territorialité à l'âge du Fer. Actes du XXIXe colloque international de l'AFEAF, Bienne, 5-8 mai 2005, volume 1. Besançon: PUFC, 2007, 55-72. (Annales Littéraires; série «Environnement, sociétés et archéologie, $11 »)$. 


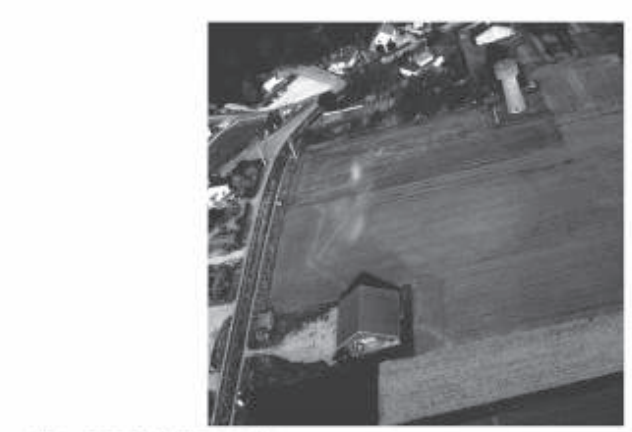

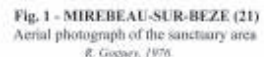

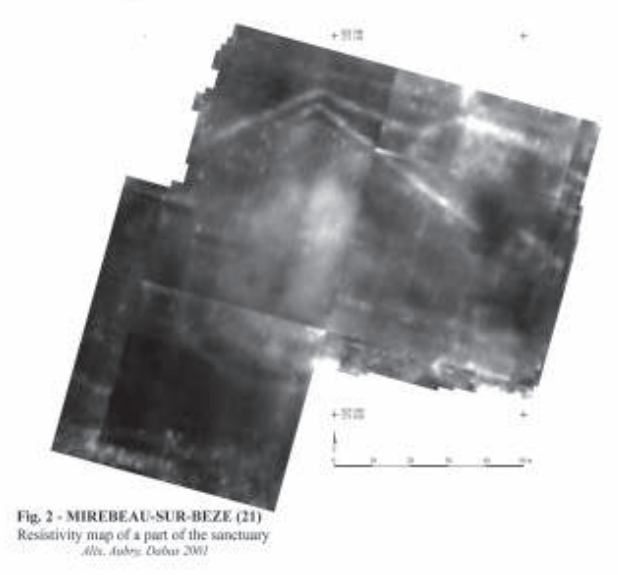

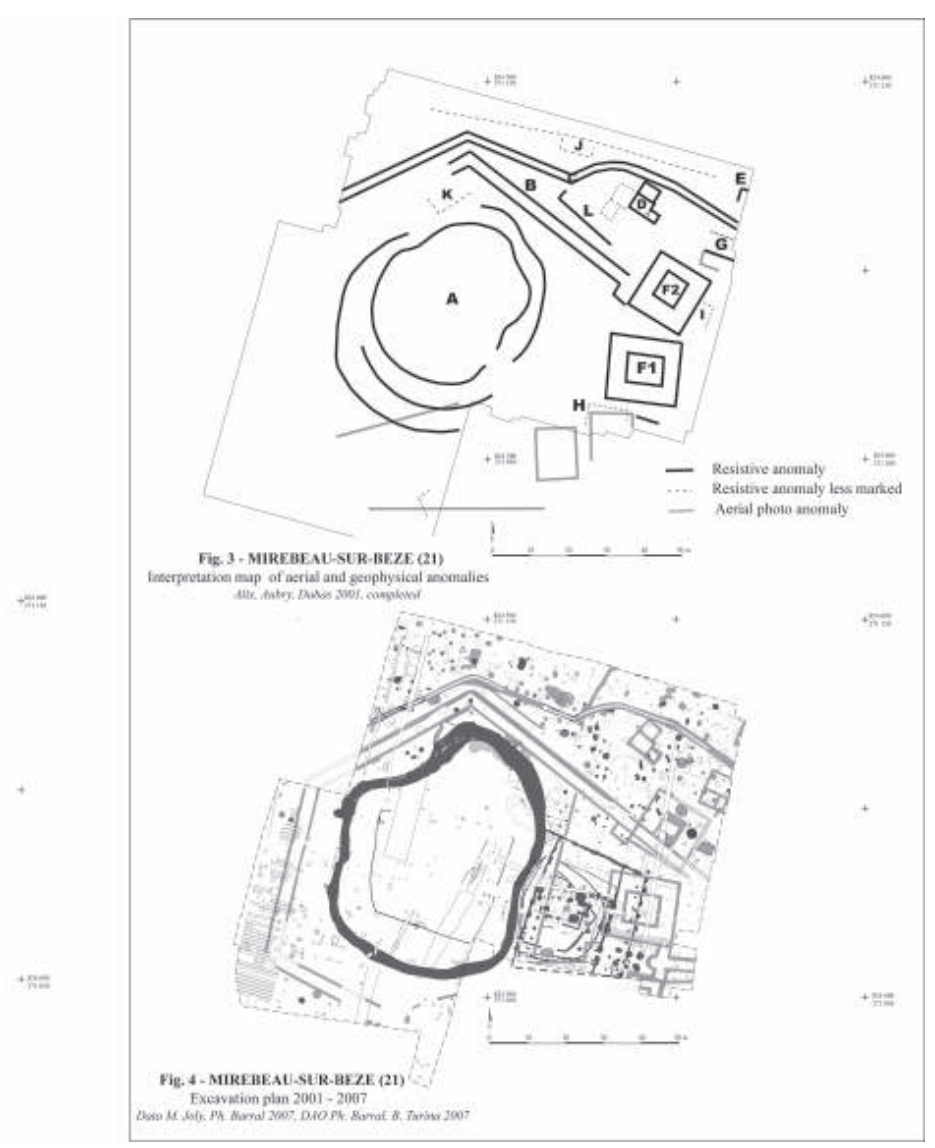

ArcheoSCiences, revue d'archéométrie, suppl. 33, 2009, p. 21-25 